\title{
Theta Roles Assigned to Subject Argument in Arabic and English Passive Voice
}

\author{
Muayad Shamsan* \\ College of Arts, University of Bisha, Kingdom of Saudi Arabia \\ Corresponding Author: Muayad Shamsan, E-mail: muahmad@ub.edu.sa
}

\begin{tabular}{l} 
ARTICLE INFO \\
\hline Article history \\
Received: July 09,2018 \\
Accepted: September 10,2018 \\
Published: December 01,2018 \\
Volume: 7 Issue: 7 \\
Advance access: October 2018 \\
Special Issue on Language \& \\
Literature
\end{tabular}

Conflicts of interest: None Funding: None

\begin{abstract}
This descriptive study sought to compare and contrast theta roles assigned to the passive voice arguments with special reference to the subject in Arabic and English. The findings of the study showed that both Arabic and English, though they belong to different language families, have close similarities concerning theta roles that could be assigned to the subject of the passive voice. The subject could have various theta roles (theme, patient, experiencer, source, goal, recipient, instrument, beneficiary, or location) in the two languages. The agent theta role could hardly be possible for a passive subject in the two languages. Agentive passive where the agent occurs in a prepositional phrase is more common in English than in Arabic. The study also showed that the recipient is preferably used as a subject of passive sentences with ditransitive verbs in the two languages. On the other hand, there are middle voice constructions in Arabic whose subject has a recipient theta role. The English counterpart for such constructions is passive voice. The study concluded that it is vitally important for Arab EFL learners to know these differences and similarities to help them understand the significance of maintaining the same theta roles of the arguments when they change sentences from active to passive or when they translate from Arabic into English or vice versa.
\end{abstract}

Key words: Passive, Theta/Semantic Role, Argument, Verb Valency, Arabic, English, Transitive, Intransitive

\section{INTRODUCTION}

Passive voice is one of the main constructions in Arabic and English languages that enables us to produce sentences where arguments other than the agent are topicalized. Passivization in Arabic and English languages involves morphological and syntactic changes. In other words, verbs in Arabic and English passive constructions are morphologically different from their active counterparts except for the English main verbs in perfect tenses. The object of active sentences is moved to the subject slot in the passive retaining the same theta role that it has in the active form. Theta role refers to the semantic relationship that clause or sentence arguments have with the main verb. It is the type of the verb (monovalent, divalent or trivalent) that plays a crucial role in determining the number of arguments and the different theta roles that these arguments are assigned in sentences. Almanna (2016) stated that, "depending on the verb per se, there are a number of noun phrases that have relations with the verb and fill different semantic roles in the clause or sentence" (p. 123). The purpose of this paper is to find out the different theta roles that the subject of the passive voice could be assigned in Arabic and English languages. It examines the common semantic roles: agent, theme, patient, experiencer, source, goal, recipient, location, beneficiary, and instrument that the arguments in Arabic and English passive constructions fill with special reference to the passive subject that might be assigned various theta roles.

\section{Statement of the Problem}

Arabic and English languages are of different origins. They have two different grammatical systems that differentiate them from one another. Many contrastive and comparative studies between Arabic and English languages have been conducted to find out whether compatible items, of a particular linguistic discipline (phonology, morphology, syntax, etc.) are alike in their structure and use or not. Such contrastive and comparative studies provide language users, learners and teachers with profound knowledge concerning the similarities and differences between the two languages at all language levels. To the best of my knowledge, I have not come across a study about Arabic and English passive voice construction in terms of theta roles that the passive arguments have. Due to lack of knowledge, Arab learners of English might assign theta roles to the arguments that are different form their original text in their performance when they change sentences from active to passive or when they translate fromArabic into English or vice versa which, consequently, 
changes the sentence meaning. Thus, the main focus of this study is on this issue with a view to gaining further insight into theta roles that the subject argument of passive construction has in both Arabic and English languages and, more significantly, identifying the shortcomings of changing arguments theta roles when translating or constructing passive sentences from their active counterparts.

\section{Questions of the Study}

The study aims to find answers to the following questions:

1. How are Arabic and English languages similar and different in terms of theta roles that the subject of the passive voice has?

2. What are the different semantic roles that could be assigned to the subject argument of passive constructions in Arabic and English?

3. Can the subject of the passive sentence have the agent theta role?

\section{LITERATURE REVIEW}

The literature review of this study has been divided into two subdivisions: verb valency, and Arabic and English passive.

\section{Verb Valency}

It is the verb that apparently plays the major role in how sentences are syntactically formed (Gruber, 1962, p. 4). "The conceptual structure of verbs might determine the number of arguments they must take" (Anonymous, n.d., p. 133). An argument is that element which completes the meaning of the verb. Adger (2002) defines an argument as "a constituent in a sentence which is assigned a $\theta$-role by a predicate" (p. 64). According to Kreidler (2002) "An account of the number of arguments that a predicate has is called the valency of that predicate" (p. 67). That is, the valency of the verb depends on the number of arguments it requires. Some verbs require one argument; some require two; and other verbs require three arguments. Kreidler (Ibid) goes on to say that verbs such as break in sentences like (The glass broke. and Ali broke the glass.) have variable valency; it has one argument in the former and two in the later (p. 68). Moreover, Kreidler (Ibid) emphasizes that weather verbs such as rain, snow, sleet and thunder have zero arguments because the subject it for these verbs does not refer to anything. However, the quasi-argument it refers to weather condition which "is required syntactically, although it is not required semantically" (Adger, 2002, p. 61).

Monovalent verbs such as run and sneeze have only one argument that is the subject of the sentence which is usually assigned the agent semantic role. Such verbs are called unergative verbs. Monovalent verbs whose subjects fill the theme theta role are called unaccusative verbs. However, divalent verbs such as see have two arguments that are the subject and the object of the sentence in active voice constructions but in passive constructions the object is promoted and becomes the subject and the subject noun phrase is postposed and follows the preposition by.
In passive constructions, 'the verb is unable to assign an agent role, some other element must take the responsibility for the assignment of this role. By is that element" (O'Grady, Dobrovolsky, \& Katamba, 1997, p. 290). Sentences with divalent or trivalent verbs could be passivized but sentences with monovalent verbs could not. English intransitive verbs cannot be passivized because the passive is formed with a transitive verb (Fredriksson, 2016, p. 2). However, in Arabic we might have passive constructions with monovalent or intransitive verbs such as جُلِسَ على الكرسي. (It was sat on the chair.). It is noteworthy that the arguments in Arabic language are not necessarily to be separate words. They could be bound morphemes affixed to the verb. In a word such as دَرَّنٌُُُ (I taught him.) the arguments are the suffixes $\stackrel{s}{\rightarrow}(\mathrm{him})$.

\section{Arabic and English Passive}

"A system of voice is one where the terms differ as to how the SYNTATIC FUNCTIONS are aligned with SEMANTIC ROLES" (Huddleston, R. \& Pullum, G. 2005, p. 240). In Arabic, passivization is derived by changing the verb pattern (vowels), i.e., the active verb vowels that follow the first consonant and precede the final consonant are changed to $-u \ldots i-$ or $-u \ldots a-$; the former pattern is used for the past tense and the later for the present tense (There are exceptions to this rule.). Moreover, the object is promoted to the subject slot and the subject is usually deleted. However, there are cases in which the subject is not deleted but demoted and becomes part of a prepositional phrase at the end of a sentence.

On the other hand, the English passive voice is a morphosyntactic operation that involves promoting the object to the subject slot, adding verb to be before the main verb to indicate tense and aspect, changing the verb morphology to the past participle form, and demoting the subject to a by phrase at the end of a sentence. It is worth mentioning here that the arguments are moved to their new slots and are assigned the same theta roles that they have in the deep structure in their active form (Ahmed \& Abdulkadir, 2013, p. 217) and (Kim \& Sells, 2007, p. 179).

In middle voice constructions, the sentence takes characteristics from both the active and passive constructions. Miller (2002) argues, "The 'middle' construction is so-called because it is felt to be intermediate between the active and passive constructions" (p. 155). In terms of syntax, the middle voice construction is similar to the active construction of monovalent verbs, but semantically it is passive-like. For instance, the sentence (The door opened.) has an active construction, but semantically it is regarded as middle voice sentence. The subject of this sentence is the theme that undergoes the action indicated by the verb. In this sentence, the door does not have the property of opening itself. It must be opened. That is, there is an external causer that facilitates its opening.

In Arabic, there are passive constructions with no subject argument as in the previously mentioned example جُلِسَ على الكرسي . The English counterpart to such constructions is made by using the impersonal pronoun it as a subject (It was sat on the chair.) or by using active voice form, (Someone sat on the chair.). 


\section{THETA ROLE IN ARABIC AND ENGLISH PASSIVE CONSTRUCTIONS}

Since the passive subject is the most common argument in passive constructions, the focus in this part is on theta roles that the passive subject might be assigned.

\section{Theta Role of the Passive Subject}

The passive subject is assigned the same theta role that it has when it is the object of its active counterpart. Fredriksson (2016) has touched on three theta roles that the subject of the passive could have in English, namely the recipient, patient and locative theta roles (pp. 37-38).

\section{a. Theme}

The theme which is used as an object NP in the active sentence can be the subject of its passive counterpart as in (1):

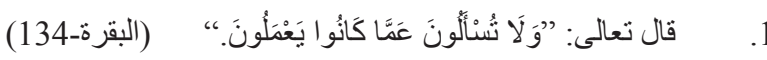

1. "And you will not be asked of what they used to do." (Albaqarah-134)

\section{b. Patient}

The patient can be the subject of a passive sentence as in (2) in which the subject of the verb يُقْنَ is invisible in Arabic.

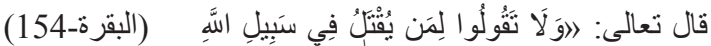

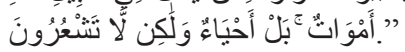

2. "And say not of those who are killed in the Way of Allah, " They are dead." Nay, they are living, but you perceive (it) not." (Albaqarah-154)

c. Experiencer

The italicized subject is the experiencer of the passive sentence in (3). It is an attached pronoun in Arabic.

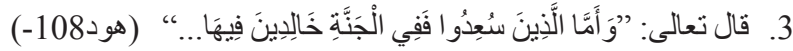

3. "And those who are blessed, they will be in Paradise,..." (Hud-108)

d. Source

The source can be the subject of the passive sentence, as in (4).

4.

4. Allah was asked for forgiveness.

e. Goal

According to Palmer (1988) ' the goal can occur as subject if the verb is passive.” (p. 91), as in (5).

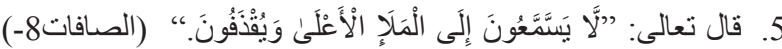

$$
\begin{aligned}
& \text { مِن كُلِّ جَانِبِ }
\end{aligned}
$$

5. "They cannot listen to the higher group (angels) for they are pelted from every side."

\section{f. Recipient}

The recipient can be the subject of a passive sentence as in (6) in which the subject of the verb يُوُْو is invisible in Arabic.

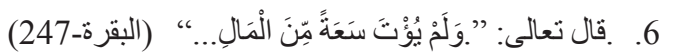

6. "... and he has not been given enough wealth..."

(Albaqarah-247)

\section{g. Location}

The word جنَّ 'hell' which is the subject of the passive sentence has the location theta role in (7).

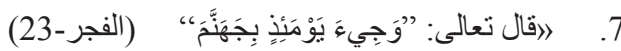

7. "And hell will be brought near that Day."

(Alfajr-23)

\section{h. Beneficiary}

The argument that is assigned the beneficiary theta role could be used as the subject in passive constructions. The italicized pronoun in (8) is the beneficiary.

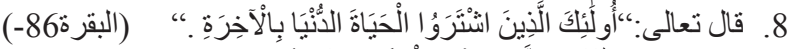

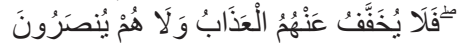

(Those are they who have bought the life of this world at the price of the Hereafter. Their torment shall not be lightened nor shall they be helped.)

\section{$i$. Instrument}

The subject of the passive sentence in (9) is the instrument.

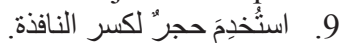

9. A stone was used to break the window.

\section{Agentivity and Passivization}

When the reflexive pronoun is the direct object in the active sentence and the sentence is passivized, the reflexive pronoun is promoted to the subject slot and takes the subject form. In (10.b) the subject pronoun is the patient that underwent a change of state and the same entity is also the agent that performed the action indicated by the verb, as it is clear in the active form in (10.a).

$$
10 \text { أ. قتل نفسه. }
$$

10. a. He killed himself.

10.

10. b. He was killed.

Arab grammarians call the passive voice ما لم بيس فاعله (a verb whose doer has not been named). They also call it نائب لما الفاعل (a substitute of the doer of the verb). Most of the Arabic passive constructions are agentless in the surface structure. Let's consider these examples:

$$
\begin{aligned}
& \text { 11. سُئنِلَ الطالبُ. } \\
& \text { 12. شُربَ الماء. }
\end{aligned}
$$

12. The water was drunk.

The abovementioned examples illustrate that though passive sentences are agentless in the surface structure, they are underlying agentive structure. If the agent has to be mentioned in Arabic, we normally use the active voice. Although most of the Arabic passive constructions are agentless, there are agentive sentences as well. The following verses from the Holy Qur'an illustrate the point:

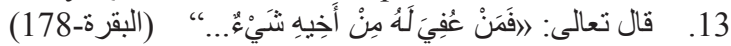

13. 'But if any remission is made by the brother..." (Albaqarah-178)

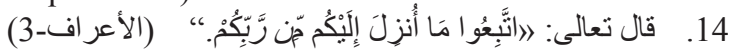

14. "Follow (O men!) the revelation given unto you from your Lord." (Ala'araf-3)

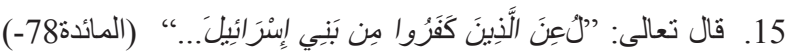

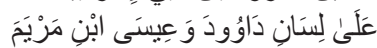

15. "Curses were pronounced on those among the children of Israel who rejected faith, by the tongue of David and of Jesus the son of Mary..." (Al-Maedah-78) 
In English, on the other hand, agentive passive constructions are commonly used. "If we wish to refer to the agent of the action, we need to use an adjunct $\mathrm{PP}$ headed by the preposition $b y$, which itself carries the notion of agentivity" (Haegeman, 1994, p. 181). Agentless passive is found in sentences where the agent is irrelevant or not known as in (16) and (17) respectively.

16. The patient was thoroughly examined.

17. My car has been stolen.

Though most of the passive constructions are agentless in Arabic language, Arab students of English encounter problems when translating agentive English passive sentences into Arabic. On the analogy of the source language, they use the literal translation when they translate the English agentive passive intoArabic equivalent structures (Khalil, 1993,p. 179).

\section{The Subject of Middle Voice}

There are verbs in Arabic that have the pattern انفعل such as اعتدل انكسر افتعل 'to be broken' or 'to break' (intrans.), انكس

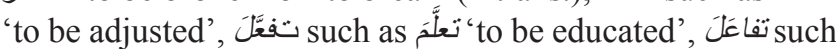

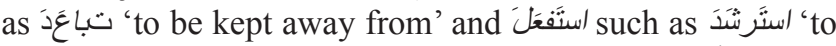
be instructed'. These verbs are called أفعال المطاوعة (middle verbs). Verbs of these patterns, as pointed out by Amayrah (2003, p. 127), may have a passive sense. Sentence (19) which is an active sentence in Arabic can express the meaning indicated by (18).

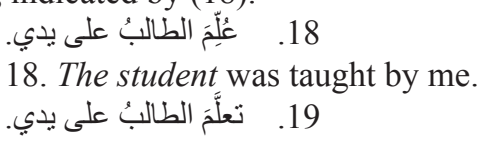

19. The student was taught by me.

The subject of middle verbs may be a recipient or a patient as in (19) and (20) respectively.

20. انكسرَ الزجاجُ (19)

20. The glass broke. or The glass was broken.

Al-Nnahas (1995) has said that the subject of middle verbs is either a recipient or that which is affected by an event performed by another entity (p. 194). These verbs have an active form but a passive function. That is why they are regarded as passive by Al-Nnahas.

There are verbs in English that may have passive sense though they have active forms. We may look at (21) and (22).

21. He opened the door.

22. The door opened.

The object of the transitive verb in (21) functions as a subject in (22). In other words, the object the door, that has the theta role of theme, is the subject in (22). However, it remains the theme in (22) as well. Sentence (22) is like agentless passive in (23):

23. The door was opened.

Thus, what is expressed by the passive form in (23) can be expressed by an active form in (22). Verbs such as open and break, therefore, can be used in their active form in sentences that convey a passive meaning.

\section{Passive Subject of Ditransitive Verbs}

The object of a transitive verb becomes the subject of its passive counterpart. Some verbs, in Arabic, require two objects in the active sentence. In such cases, the active sentence may have two passive counterparts, for instance, (24) has (25) and (26) as its passive counterparts:

$$
\text { 24. أُعطى الطبيبُ المريضَ دواءً. }
$$

24. The doctor gave the patient medicine.

$$
\text { 25. أعطبيَ المريضنُ دواءً. }
$$

25. The patient was given medicine.

$$
\text { 26 }
$$

26. Medicine was given to the patient

Aljurjani (1982) has pointed out that it is better to use the recipient (the indirect object) as a subject of the passive sentence as in (25) because the indirect object performs the action of receiving, like the subject of the active sentence in (24) that performs the action of giving, but the direct object performs nothing at all (p. 351). The second reason is that the recipient (the indirect object) is nearer to the subject in the active form. That is why it replaces the subject when the sentence is passivized. Both of these arguments seem to be weak. If they were correct, we couldn't have had (26) in which دواء 'medicine' is the subject of the passive sentence, even though it is the theme and is away from the subject in the active sentence.

All transitive verbs can be used in the passive voice in English. Like in Arabic, English ditransitive verbs can have two passives as in (27. b. and c.).

27. a. I gave him a book.

b. He was given a book.

c. A book was given to him.

In (27.b), the recipient (indirect object) becomes the subject of the passive sentence, but in (27.c), the theme (direct object) is the subject of the passive sentence. Like Aljurjāniy,(1982), Gelderen, (2010) has the same previously mentioned opinion about using the recipient (indirect object) as a subject of the passive sentence because the greater interest is felt for the person than for things.

\section{FINDINGS OF THE STUDY}

The analysis of the passive voice arguments theta roles showed the following findings that provide answers to the questions raised in the introduction.

1. Although Arabic and English are of different origins, they show remarkable similarities in terms of theta roles that are assigned to the subject of the passive voice.

2. The subject of the passive voice sentence, which has the same semantic role of the object in its active deep structure, might be assigned the theme, patient, experiencer, source, goal, recipient, location, instrument or beneficiary theta role in Arabic and English languages.

3. Sentences with ditransitive verbs could have two passive counterparts and the subject is assigned the recipient or theme theta role in the two languages; the recipient is preferred to be the subject of the passive.

4. Arab grammarians such as Aljurjāniy (1982) and English grammarians such as Gelderen (2010) are of a single mind about using the recipient (indirect object of the active sentence) as the subject of the passive sentence in sentences with ditransitive verbs because that way a greater interest is shown in the person than in things.

5. Concerning agentivity, the study showed that when the same entity is assigned the agent and patient theta roles 
in the active voice, the passive voice could be used and the passive subject is assigned both the agent and patient theta roles as in (10) which hardly occurs in both the languages.

6. In Arabic, middle verbs have active form but passive sense (Amayrah, 2003, p. 127) and (Al-Nnahas, 1995, p. 194). The subject of these verbs may have a recipient or a patient/theme theta role. The English counterpart for Arabic middle voice sentences whose subject has the recipient theta role is passive voice as in (19).

\section{CONCLUSIONS AND IMPLICATIONS}

Thus, this study focuses of the various theta roles assigned to the subject of the passive voice in Arabic and English languages. It was found that the subject of the passive voice in both the languages could be assigned the same theta roles in spite of the fact that Arabic and English belong to different families. Concerning agentive passive constructions, the study showed that agentive passive is more common in English than in Arabic. Moreover, active voice constructions whose subject has a recipient theta role in Arabic are passivized in English. The findings of the study imply the significance of maintaining the arguments' theta roles when changing sentences from active to passive or when translating from one language into another.

This study, though theoretical, has some significant implications for Arab EFL learners. The findings of the study shed light on one of the vitally important problems that Arab learners of English might face. In other words, they help them to be more aware of the drawbacks of altering arguments' theta role when changing sentences from active to passive or when translating from Arabic into English or vice versa because "'changing the semantic roles filled by these arguments will definitely create slightly or completely different mental images and messages" (Almanna, 2016, p. 128). In addition, the study addresses English language instructors to direct their students to take this issue into account in their learning process.

\section{RECOMMENDATIONS}

This study has not touched on all the points relevant to the topic. Therefore, a study on semantic role shifting in Arabic-English translation by Arab undergraduate students is needed to examine the consequences of changing the arguments theta roles in their translation. Another corpus-based study on the subject of the passive voice theta roles might be required to see which of the theta roles could be more frequently assigned to the subject. Moreover, a study on verb categorization according to theta roles that the verb assigns to the different arguments could be conducted as well.

\section{REFERENCES}

Adger, D. (2002). Core Syntax: A Minimalist Approach. Retrieved from http://www.pnu.ac.ir/portal/File/ShowFile.aspx?ID=c3f3731d-8509-45df-afc9-35b5fbcddd8e $(28 / 3 / 2018)$

Ahmed, A. \& Abdulkadir S. (2013). Passivization and Theta $(\theta)$ Role in Arabic and Fulfulde. Retrieved from http:// www.languageinindia.com/may2013/passivizationfulfuldearabic.pdf

Almanna, A. (2016). Semantics for Translation Students. New York: Peter Lang.

Anonymous. (n.d.). The Structure of the Verb Phrase (pp. 133167). Retrieved from http://www.unibuc.ro/prof/ avram_1/docs/2012/noi/25_00_27_16Avram_2006_ Chapter 3.pdf

Fredriksson, A. L. (2016). A corpus-based contrastive study of the passive and related constructions in English and Swedish (Ph.D. Thesis). Gothenburg: University of Gothenburg. Retrieved from https://gupea.ub.gu.se/bitstream/2077/41822/2/gupea_2077_41822_2.pdf

Gelderen, E. (2010). An Introduction to the Grammar of English (Revised ed.). Amsterdam/Philadelphia: John Benjamins Publishing Company.

Gruber, J. S. (1962). Studies in Lexical Relations (Ph.D. Thesis). Massachusetts Institute of Technology.

Haegeman, L. (1994). Introduction to Government and Binding Theory. Oxford: Blackwell.

Huddleston, R. and Pullum, G. (2005). A Student $>$ Introduction to English Grammar. USA: Cambridge University Press.

Khalil, A. (1993). Arabic Translations of English Passive Sentences: Problems and Acceptability Judgements. $\mathrm{Pa}$ pers and Studies in Contrastive Linguistics vol. XXVII, Poznań: Adam Mickiewicz University. Retrieved from http://wa.amu.edu.pl/psicl/files/27/12Khalil.pdf

Kim, J. B. \& Sells, P. (2007). English Syntax: An Introduction. Stanford, CA: Center for the Study of Language and Information.

Kreidler, C. W. (1998). Introducing English Semantics (ed. 2002). USA and Canada: Taylor \& Francis e-Library.

Miller, J. (2002). An Introduction to English Syntax, UK: Edinburgh University Press

O’Grady, W., Dobrovolsky, M., \& Katamba, F. (1997). Contemporary Linguistics: An Introduction. UK: Longman.

Palmar F. R. (1988). The English Verb. London: Longman. الجرجاني عبد القاهر (1982). كتاب المقتصد في شرح الإيضاح. تحقيق المران

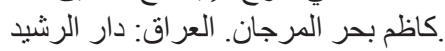

عمايرة اسماعيل أحمد (2003). دراسات لغوية مقارنة. عمان, الأردن:

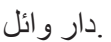

النحاس مصطفى (1995). من قضايا اللغة. الكويت: جامعة الكويت دار 